\title{
Risk of Material Misstatement in the Stage of Audit Planning: Empirical Evidence from Vietnamese Listed Enterprises
}

\author{
Hoan NGUYEN*, Thi Kieu Trang NGO**, Thi Tam LE*** \\ Received: January 01, 2020 Revised: January 30, 2020 Accepted: February 06, 2020.
}

\begin{abstract}
The purpose of this study is to investigate factors influencing risk assessment of material misstatement in Vietnamese enterprises listed on stock market. Expert interview method was conducted to discover the scales for three variables including information system, trademark, and risk assessment of material misstatement. Survey method was used to examine the impacts of eight factors on risk assessment of material misstatement. Data is collected from 317 auditors who have excellent experience in auditing financial statements of companies listed on stock market. Then, data is processed by descriptive statistics, reliability analysis, factor extracted analysis, correlative regression analysis, and analysis variance of residual change. The research findings showed that business characteristic, stakeholder pressure, and economic environment have positive relationships with risk assessment of material misstatement. Three variables including operation control and monitor, control environment, and information system negatively affect to risk assessment. Specially, business characteristic and information system, which are elements in internal control, have strongest impact on risk assessment. One the other hand, assessment of internal control plays an important role not only in the audit plan stage but also throughout the stages of the audit implementation and ending. Therefore, appropriate solutions are proposed to carry out all audit stages.
\end{abstract}

Keywords : Material Misstatement, Risk Assessment, Audit Plan, Listed Enterprise, Vietnam

JEL Classification Code: G32, M21, M42

\section{Introduction}

In the current market economy, auditing is one of sectors interested in and trust by society. Demand of society for auditing profession is rapidly increasing which require auditors and audit firms to improve both professional competence and audit services. The audit report is the basis for a third party to search for information and make its investment decisions. In the growing economic situation,

*First Author, Lecturer, Faculty of Economics, Natural Resources and Environment, Hanoi University of Natural Resources and Environment, Vietnam. Email: hoannx.nd@gmail.com.

**Lecturer, Faculty of Economics, Natural Resources and Environment, Hanoi University of Natural Resources and Environment, Vietnam. Email: kieutrang240286@gmail.com

${ }^{* * *}$ Corresponding Author. Lecturer, Department of Accounting, Thuyloi University, Vietnam [Postal Address: No. 175, Tay Son Street, Dong Da District, Hanoi, 100000, Vietnam]

Tel. +84984537282, Email: lethitam@tlu.edu.vn

() Copyright: The Author(s)

This is an Open Access article distributed under the terms of the Creative Commons Attribution NonCommercial License (https://creativecommons.org/licenses/by-nc/4.0/) which permits unrestricted noncommercial use, distribution, and reproduction in any medium, provided the original work is properly cited. the need to expand the scale and business fields is rapid. As a result, the complexity of accounting and auditing in enterprises listed on stock market is also more. Therefore, auditors are also difficult to detect fraud in the financial statements.

In the world, the collapse of Enron Energy Corporation, Worldcom, Tyco International, Peregrine Systems, Olympus, and Health South Group resulted from fraud of financial statements (Rahman, Meah, \& Chaudhory, 2018). When performing the audit contract, auditing firms did not detect the material misstatement from frauds, so opinions on the financial statements are inaccurate, which seriously affect the users and reputation of audit firms. The reason is that auditors often face difficulties in applying audit procedures to detect risks of material misstatement in auditing financial statements (Coderre, 1999; Dikmen \& Küçükkocaoğlu, 2010). The dishonesty of managers when making announcements about financial statements comes from the purpose of maintaining the stock price and their reputation (Jensen \& Meckly, 1976). In addition, audit firms have not focused on evaluating control risks, potential risks, and internal control system, but mainly based on 
subjective opinions of auditors, and pressure on the time to complete auditor's work. On the other hand, audit firms, which want to survive and develop, are also under pressure on revenue and competition. Therefore, the quality and duration of the audit have a great influence on the choices of clients.

Assessing the risk of material misstatement in the audit plays an important role especially in the audit planning stage, which has a decisive influence on the quality of the audit. The stage is a crucial part and takes a lot of time. Therefore, a reasonable and scientific risk assessment of material misstatement in auditing financial statements should be paid attention and monitored by audit firms in the planning process.

Currently, in Vietnam, there have been many published studies on financial statements audits. However, there has not been any topic into the field of risk assessment with material misstatement during the audit planning in Vietnamese enterprises listed on stock market. The purpose of this study is to examine factors, which affect risk assessment of material misstatement during the audit planning stage.

\section{Literature Review}

Norman, Lombard, Wright, Kopral, Rodriguez, and Miller (2011) indicate that the characteristics of internal control committee affect the reliability of financial statements. The risk of material misstatement may be caused by business risk and control risk. The first study on fraud in the financial statements is of Romney, Albrecht, and Cherrington (1980) who gave 87 red flags to predict fraud. They concluded that the above signs are essential in detecting frauds and predicting integrity of the Director Board. Moreover, Loebbecke, Eining, and Willingham (1989) provided a predictive model of the errors risk by fraud that is supported by Bell and Carcello (2000), Nieschwietz, Schultz, and Zimbelman (2000), and Wilks and Zimbleman (2004).

Risks of material misstatement often occur in the balance sheet (Albrecht, Albrecht, Albrecht, \& Zimbelman, 2011; Brazel, Jones, \& Zimbelman, 2009; Kreutzfeldt \& Wallace, 1986; Schultz, Bierstaker, \& O'Donnell, 2010). Previous studies concurred that the frequency of misstatement risk, which appear in indicators such as revenue, customer receivables and inventory is higher than other indicators on the balance sheet.

One of the reasons for the risks in the financial statements is caused by managers who intentionally conceal to make difficultly in detecting risks (Jensen \& Meckly, 1976) aimed at avoiding damages about their personal property and reputation (Kothari, Shu, \& Wysocki, 2009).
The risks were discovered easily when enterprises went bankrupt (Anderson \& Yohn, 2002; Ettridge, Scholz, Smith, \& Sun, 2010; Palmrose, Richardson, \& Scholz, 2004; Srinivasan, 2005). In addition to that, management practice is main cause of misstatement risk (Curtis, Lundholm, \& Mcvay, 2013; Riley, Preason, \& Trompeter, 2003). Keune (2010) assessed the risk of material misstatement by fraud and focused on the fraudulent performance of revenue, receivables and inventory accounts. Compared to previous studies that only concentrated on an item, Keune (2010) expanded many fraudulent accounts.

Many studies used adjusted accrual model to predict fraud of financial statements such as Healy (1985) followed by Jone (1991), DeAngelo, DeAngelo, and Skinner (1994), Friedlan (1994). Adjusted accrual mode is a tool to detect the possibility of fraud in the financial statements if there are abnormal differences which is based on standards and regulations on accrual levels between the reported number and the expected number. DeAngelo, DeAngelo, and Skinner (1994) and Jones (1991) focused on adjusting revenue through adjusting accrual variables.

Beneish (1999) was one of the pioneers on building a model to predict the fraud of financial statements, called MScore ratio in order to help auditors and investors assess whether or not the fraud possibility of financial statements appear. The model can detect potentially fraud accounting for $76 \%$ of predicting probability. Students in Cornell University dawn Enron's fraud before a year when the company went bankrupt. Based on M Score model, Dikmen and Küçükkocaoğlu (2010) developed a model to find frauds in the financial statements of 126 enterprises listed on stock market in Turkey. Dikmen and Küçükkocaoğlu (2010) added two variables in the model including inventory index (DINV) and financial cost index (FEI) that help Capital Markets Board of Turkey forecast $81 \%$ of adjusted income. Chae, Nakano, and Fujitani (2020) used a model to verify the positive and significant relationship between financial reporting opacity measured by the company's earnings management behavior and crash risk in Japanese listed companies. In which, crash risk consists of three variables CRASH, NSKEW, DUVOL.

Based on Beneish's research model, Marinakis (2011) discovered three additional variables consisting of: EFTAXI - Effective tax rate, DIRAI - remuneration index for directors on total Assets, AUDI - Audit remuneration index on total assets. The model of Marinakis (2011) has 10\% higher accuracy than Beneish's. F-score model of Dechow, Ge, Larson, and Sloan (2011) studied 2190 listed companies in the period of 1982-2005. They claimed that when $\mathrm{F}$ - score is greater than 1 , financial statements are more likely to be fraudulent and therefore revenue is adjusted. After conducting the audit, it is concluded that Fscore 1 model correctly forecast $65.9 \%$, F-sore 2 by $65.78 \%$, 
and $\mathrm{F}-$ score 3 of $63.36 \%$.

As mentioned above, most of the research on risk assessment of material misstatement in financial statement audit is only limited to the following issues:

First, assessing risks of material misstatement on the financial statements, auditors usually focus on such criteria as inventory, customer receivables, etc. Reasons is that business characteristics of the enterprises significantly affect to these indicators compared to other indicators on balance sheet.

Second, when conducting audits and collecting audit evidence to assess the risks of material misstatement, auditors have difficulty performing audit procedures, and evaluating errors with material misstatement. The lack of flexible application of auditing techniques also affects the results of risk assessment.

Third, in Vietnam, very little research on the risk assessment of material misstatement are appeared. In particular, no study has examined the factors that affect risk assessment results by characteristics of material misstatement during the audit planning stage.

\section{Research Method}

\subsection{Method of Interviewing Experts}

In order to identify the factors affecting risk assessment of material misstatement in auditing financial statements, authors conduct expert interviews related to the research field. Interview process is as follows:

Step 1: The authors prepare questionnaire to interview auditors related to the factors affecting the risk assessment of misstatements from internal control which is performed by auditors.

Step 2: Interviewing 20 experienced auditors at audit firms which have enough conditions to audit at listed enterprises. Each interview which took place from 60 minutes to 90 minutes is conducted by face-to-face or via telephone. Open and close questions are used to collect research information. Because information is aggregated according to saturation theory, after the interview, the authors remove the tape, and process the information sequentially.

The interview results are summarized as follows:

Firstly, in the stage of audit planning, auditors learns about trademark of enterprises on the following items such as: reputation of enterprises in the field, position of enterprises in professional associations, Reputation of enterprises in many years, credibility in the field of finance. Besides, when assessing of misstatement risk during the audit planning stage, auditors pay attention to evaluation of client's operational characteristics.
Secondly, based on the audit records, the factors affecting assessment of misstatement risk include Qualifications of auditors, risk assessment model, internal control and risk prevention of clients, the effectiveness and efficiency of internal auditors, the experience of the audit team. Then, the interview results are used in the survey method.

\subsection{Survey Method}

From the findings of the relationship between risk assessment of material misstatement and the impacted factors, the survey was conducted. The questionnaire consists of 2 parts. Part 1 is general information of auditors such as gender, age, and work experience. Part 2 includes questions about the factors affecting risk assessment of misstatement errors. 5-point Likert scale is used to measure observed variables range from 1 to 5 (1 totally disagree, 5 completely agree) (see Appendix 1).

First, the questionnaire was sent to the audit experts, before delivering to a large scale. After receiving feedback from the subjects, the authors edited the survey question and conducted a large scale survey with 390 auditors by online in 2019, which then collected 317 valid votes.

Data collected was processed by SPSS 22.0 to perform descriptive statistics, reliability analysis of scales, factor extracted analysis, correlative regression analysis, analysis variance of residual change, and examine the impact of factors on risk assessment of material misstatements.

Houston, Peters, and Pratt (1999) concluded that assessing risks of significant misstatement needed analysis of business strategies. In order to capture information, it is necessary to learn about control environment, risk assessment process, operation control, monitoring controls, and information systems. Factors affecting the risk assessment of material misstatement in this study are proposed in Figure 1.

Control Environment: The control environment includes elements related to management views and style about internal control. Good control environment will help members clearly define their responsibilities and information circulated transparently and accurately. As a result, it will reduce the risk of significant errors in financial statements.

H1: Control environment has negative relationship with risk assessment of material misstatement.

Process of Risk Assessment: The risk assessment process of an enterprise includes how the board of directors identifies risks in business activities associated with the preparation and presentation of the financial statements; assess the likelihood of risks and decide actions to handle and manage risks. Therefore, if board of directors has 
financial risk management and monitor activities, the risk of significant errors will be limited.

H2: Process of risk assessment has negative relationship with risk assessment of material misstatement.

Operation Control: Operation control includes the evaluation and analysis of the actual operational situation compared with the plan, or the operation situation of the previous period; evaluate and analyze the relationships between the various related data, such as financial data, and perform discovery and correction; compare internal data with external sources and evaluate the performance of functions or activities. Good control practices reduce the risks of significant misstatements.

H3: Operation control has negative relationship with risk assessment of material misstatement.

Monitoring Control: Monitoring controls is a supervisory inspection of regulations, control mechanisms, operation of internal control on issues such as: completeness, accuracy, or timeliness of the rules. The people who implement the management regulations, consist of leader or specialized staff. Mechanism of controls helps clients limit significant errors.

H4: Monitoring controls has negative relationship with risk assessment of material misstatement.

Information System: In the process of setting up a report, the information is not only transmitted orally but mainly transmitted through technological equipment such as computers and business software. A well-controlled, modern information system will reduce accidental errors during the reporting process. Therefore, improving the information system will help to prevent the risks of significant errors in the financial statements.

H5: Information system has negative relationship with risk assessment of material misstatement.

Trademark: Trademark is associated with the enterprise's reputation. Big brand enterprises will become more popular. Therefore, the enterprises will get more attention than with small brands. As a result, the control of assessing errors in audit reports has been paid more additions. However, for large enterprises, the audit processes are always scrutinized which limit the risks of significant errors. Brand also causes auditors to be under certain pressure and subjectivity in the process of evaluating risk of significant misstatements such as the bankruptcy of audit firm like Arthur Anderson.

H6: Trademark has negative relationship with risk assessment of material misstatement.

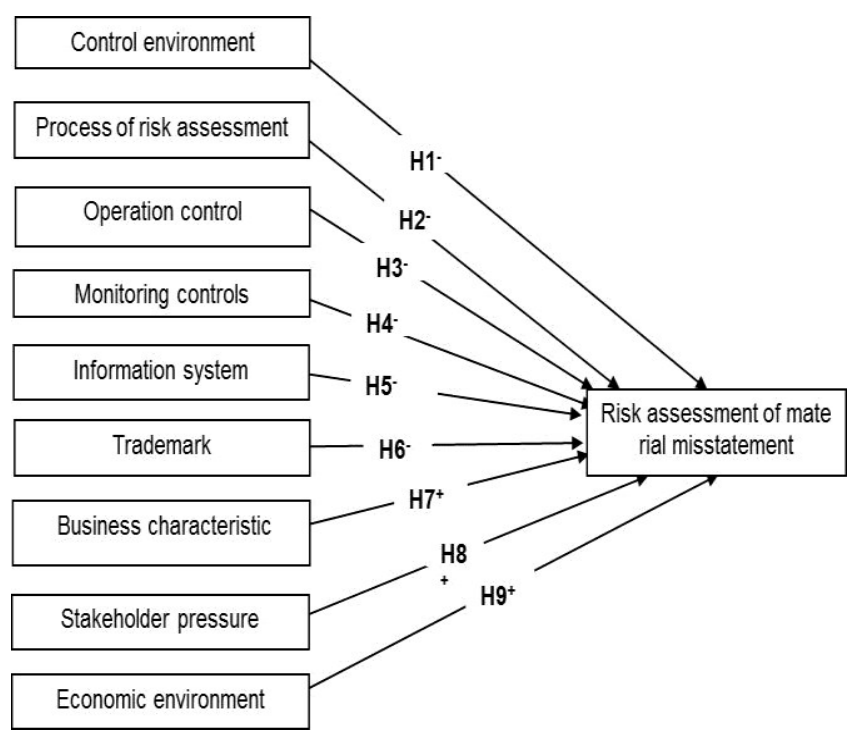

Figure: 1: Research model in audit planning stage

Business Characteristic: The indexes of doubtful debts and the provision for devaluation of inventories are usually subjectively assessed and evaluated by accountants to affect the financial statement in most types of enterprises. Loebbecke, Eining, and Willingham (1989) and Summers and Sweeney (1998) agree that the possibility of high fraud in the financial statements is derived from receivables account and inventory. This shows that the ability of significant misstatements in the financial statements depends on enterprise characteristics. The accountants put subjective opinions into the accounts such as receivables, liabilities, and inventory to influence on financial statements according to the individual's wishes.

H7: Business characteristic has positive relationship with risk assessment of material misstatement.

Stakeholder Pressure: Dechow, Sloan, and Sweeney (1996) showed that enterprises with high financial leverage and loan guarantee terms will be motivations to conduct governing the revenue level of enterprises. The higher the levels, the more enterprises tend to increase profits through accounting criteria (DeAngelo, DeAngelo, \& Skinner, 1994; DeFond \& Jiambalvo, 1991). Therefore, the abilities, which are under pressure from short-term debt, or stakeholder pressure will increase (Beneish, 1999; Lou \& Wang, 2011; Skousen, Smith, \& Wright, 2009).

H8: Stakeholder pressure has positive relationship with risk assessment of material misstatement.

Economic Environment: Zheltoukhova and Suckley (2014) argued that the economic environment affects both the management capacity of leaders, their decision making and strategic planning. As a result, the risks of significant 
misstatements in the financial statements are greatly impacted by the decisions of managers. The more complex economic environment is, the higher risk assessment of material misstatement is.

H9: Economic environment has positive relationship with risk assessment of material misstatement.

\section{Research Results}

\subsection{Survey Respondents}

In Table 1, about gender, the number of male and female auditors is relatively uniform. There are 161 female accounting for $50.8 \%$ and 156 male (49.2\%). For ages, auditors from 25 to 35 years account for $64.3 \%$, between 36 and 45 years by $31.9 \%$, and more than 45 years of $3.8 \%$. With the work experience, auditors with experience less than 5 years occupy of $7.3 \%$, from 5 to 10 years by $48.3 \%$, from 11 to 15 years equal to $37.9 \%$, and more than 15 years reaching $6.6 \%$, suggesting that the work experience is mainly from 5 to 15 years. Respondents with high experience make sure reliability for answers.

Table 1: General information about respondents

\begin{tabular}{|c|c|c|}
\hline & $\begin{array}{l}\text { Number of } \\
\text { respondents }\end{array}$ & Percentage rate \\
\hline \multicolumn{3}{|c|}{ Gender } \\
\hline Male & 156 & $49,2 \%$ \\
\hline Female & 161 & $50,8 \%$ \\
\hline \multicolumn{3}{|c|}{ Ages } \\
\hline From 25 to 35 & 204 & $64,3 \%$ \\
\hline From 36 to 45 & 101 & $31,9 \%$ \\
\hline Above 45 & 12 & $3,8 \%$ \\
\hline \multicolumn{3}{|c|}{ Work experience } \\
\hline Less than 5 years & 23 & $7.3 \%$ \\
\hline From 5 to 10 years & 153 & $48.3 \%$ \\
\hline From 11 to 15 years & 120 & $39.9 \%$ \\
\hline More than 16 years & 21 & $6.6 \%$ \\
\hline
\end{tabular}

\subsection{Verifying the Reliability of the Scale}

The results of Table 2 show that Cronbach's Alpha of all variables range from 0.708 to 0.912 (greater than 0.6), Cronbach's Alpha if item deleted coefficients are greater than 0.6, and Correlated total variable coefficient are greater than 0.3 . It insists that all items have high reliability.
Table 2: Reliability of items

\begin{tabular}{|c|c|c|c|}
\hline Items & $\begin{array}{c}\text { Cronbach's } \\
\text { Alpha }\end{array}$ & $\begin{array}{l}\text { Correlated total } \\
\text { variable }\end{array}$ & $\begin{array}{c}\text { Cronbach's Alpha if } \\
\text { item deleted }\end{array}$ \\
\hline RAM1 & \multirow{4}{*}{.856} & .697 & .800 \\
\hline RAM2 & & .654 & .770 \\
\hline RAM3 & & .524 & .746 \\
\hline RAM4 & & .683 & .819 \\
\hline CE1 & \multirow{3}{*}{.830} & .649 & .749 \\
\hline CE2 & & .577 & .822 \\
\hline CE3 & & .758 & .635 \\
\hline PRA1 & \multirow{4}{*}{.912} & .653 & .886 \\
\hline PRA2 & & .728 & .852 \\
\hline PRA3 & & .850 & .803 \\
\hline PRA4 & & .753 & .841 \\
\hline OC1 & \multirow{4}{*}{.864} & .724 & .821 \\
\hline $\mathrm{OC} 2$ & & .680 & .842 \\
\hline OC3 & & .714 & .826 \\
\hline OC4 & & .749 & .812 \\
\hline $\mathrm{MC} 1$ & \multirow{4}{*}{.835} & .655 & .796 \\
\hline MC2 & & .635 & .806 \\
\hline MC3 & & .723 & .764 \\
\hline MC4 & & .662 & .796 \\
\hline IS1 & \multirow{3}{*}{.795} & .679 & .681 \\
\hline IS2 & & .655 & .703 \\
\hline IS3 & & .586 & .780 \\
\hline TR1 & \multirow{4}{*}{.708} & .498 & .645 \\
\hline TR2 & & .446 & .682 \\
\hline TR3 & & .498 & .648 \\
\hline TR4 & & .584 & .612 \\
\hline $\mathrm{BC} 1$ & \multirow{3}{*}{.825} & .817 & .616 \\
\hline $\mathrm{BC} 2$ & & .779 & .658 \\
\hline $\mathrm{BC} 3$ & & .590 & .738 \\
\hline EE1 & \multirow{3}{*}{.855} & .718 & .682 \\
\hline EE2 & & .718 & .688 \\
\hline EE3 & & .564 & .812 \\
\hline SP1 & \multirow{3}{*}{.888} & .633 & .795 \\
\hline SP2 & & .602 & .809 \\
\hline SP3 & & .619 & .812 \\
\hline
\end{tabular}

\subsection{Extracted Factor Analysis}

In Table 3, KMO value is equal to 0.744 greater than 0.5 ; The p-value of Barlett's test is 0.000 less than 0.05 and the 
variance extracted by $70.23 \%$ is greater than $50 \%$, showing that the factor analysis is consistent with the research data. There are 8 factors formed in which $\mathrm{OC}$ and $\mathrm{MC}$ converge into 1 factor called OCMC, other factors converge as the initial hypothesis.

Table 3: Factor analysis for independent variables

\begin{tabular}{|c|c|c|c|c|c|c|c|c|}
\hline & \multicolumn{7}{|c|}{ Main ingredients } \\
\hline & $\mathbf{1}$ & $\mathbf{2}$ & $\mathbf{3}$ & $\mathbf{4}$ & $\mathbf{5}$ & $\mathbf{6}$ & $\mathbf{7}$ & $\mathbf{8}$ \\
\hline MC3 & .794 & & & & & & & \\
\hline OC3 & .785 & & & & & & & \\
\hline OC4 & .781 & & & & & & & \\
\hline MC4 & .748 & & & & & & & \\
\hline MC1 & .743 & & & & & & & \\
\hline OC1 & .733 & & & & & & & \\
\hline OC2 & .731 & & & & & & & \\
\hline MC2 & .679 & & & & & & & \\
\hline PRA3 & & .880 & & & & & & \\
\hline PRA4 & & .844 & & & & & & \\
\hline PRA2 & & .821 & & & & & & \\
\hline PRA1 & & .785 & & & & & & \\
\hline SP1 & & & .922 & & & & & \\
\hline SP3 & & & .861 & & & & & \\
\hline SP2 & & & .839 & & & & & \\
\hline EE3 & & & & .823 & & & & \\
\hline EE2 & & & & .804 & & & & \\
\hline EE1 & & & & .795 & & & & \\
\hline TR4 & & & & & .790 & & & \\
\hline TR1 & & & & & .742 & & & \\
\hline TR3 & & & & & .731 & & & \\
\hline TR2 & & & & & .675 & & & \\
\hline CE3 & & & & & & .868 & & \\
\hline CE1 & & & & & & .813 & & \\
\hline CE2 & & & & & & .726 & & \\
\hline BC1 & & & & & & & .881 & \\
\hline BC2 & & & & & & & & \\
\hline BC3 & & & & & & & & \\
\hline IS1 & & & & & & & & \\
\hline
\end{tabular}

KMO value in Table 4 is of 0.782 greater than 0.5 ; The p-value of Barlett's test is 0.000 less than 0.05 and the variance extracted by $70.51 \%$ is greater than $50 \%$, which shows that the factor analysis is consistent with the research data.

Table 4: Factor analysis for dependent variables

\begin{tabular}{|c|c|}
\hline \multirow{2}{*}{} & Main ingredients \\
\cline { 2 - 2 } & $\mathbf{1}$ \\
\hline RAM3 & .924 \\
\hline RAM2 & .881 \\
\hline RAM1 & .840 \\
\hline RAM4 & .698 \\
\hline KMO & $\mathbf{0 . 7 8 2}$ \\
\hline p-value of Bartlett & $\mathbf{0 . 0 0 0}$ \\
\hline Variance extracted & $\mathbf{7 0 . 5 1 \%}$ \\
\hline
\end{tabular}

\subsection{Correlation Analysis}

The results of Table 5 point out that IS variable has the strongest correlation with RAM (-0.643), followed by the $\mathrm{CE}$ variable (-0.445) and the weakest correlation variable with RAM is the PRA variable (0.034) which means that the risk assessment process has not close relationship with risk assessment of material misstatement.

Table 5: Correlation matrix

\begin{tabular}{|c|c|c|c|c|c|c|c|c|c|}
\hline & RAM & OCMC & CE & PRA & BC & SP & IS & TR & EE \\
\hline RAM & 1 & & & & & & & & \\
\hline OCMC & $-.130^{*}$ & 1 & & & & & & & \\
\hline CE & $-.445^{* *}$ & .048 & 1 & & & & & & \\
\hline PRA & -.034 & .098 & .108 & 1 & & & & & \\
\hline BC & $.356^{* *}$ & $-.160^{* *}$ & $-.232^{* *}$ & -.036 & 1 & & & & \\
\hline SP & $.181^{* *}$ & $.210^{* *}$ & $-.132^{*}$ & $-.374^{* *}$ & .076 & 1 & & & \\
\hline IS & $-.643^{* *}$ & $.174^{* *}$ & $.443^{* *}$ & -.024 & $-.203^{* *}$ & -.037 & 1 & & \\
\hline TR & .078 & $-.115^{*}$ & $-.115^{*}$ & -.017 & $.124^{*}$ & -.003 & $-.171^{* *}$ & 1 & \\
\hline EE & $.395^{* *}$ & $.130^{*}$ & $-.186^{* *}$ & .047 & .040 & $.159^{* *}$ & $-.265^{* *}$ & .010 & 1 \\
\hline
\end{tabular}

\subsection{Regression Analysis}

According to Table 6, R-Square value is of $0.664>$ 0.5 proving that the model is highly reliable. Adjusted $\mathrm{R}$ square is equal to 0.648 , which indicates that the independent variables affect $64.8 \%$ to the dependent variable. Durbin-Watson value is of 1.487 belong to from 1 to 2 , showing that the model does not have autocorrelation. Moreover, the sig value of the ANOVA table is $0.000<0.05$, reflecting that the regression 
model was built in accordance with the collected data.

Table 6: Model Summary ${ }^{\mathrm{b}}$

\begin{tabular}{|c|c|c|c|c|c|}
\hline Model & $\mathbf{R}$ & R Square & $\begin{array}{c}\text { Adjusted R } \\
\text { Square }\end{array}$ & $\begin{array}{c}\text { Std. Error of the } \\
\text { Estimate }\end{array}$ & $\begin{array}{c}\text { Durbin- } \\
\text { Watson }\end{array}$ \\
\hline 1 & $.801^{\mathrm{a}}$ & .640 & .632 & .39273 & 1.487 \\
\hline \multicolumn{6}{|c|}{ a. Predictors: (Constant), OCMC, CE, PRA, BC, SP, IS, TR, EE } \\
\hline \multicolumn{6}{|c|}{ b. Dependent Variable: RAM } \\
\hline
\end{tabular}

Variables which have sig. values are less than or equal to 0.05 , impact on the dependent variable (Gujarati \& Porter, 2008; Hair, Black, Babin, Anderson, \& Tatham, 2006) and if the variables have sig. $>0.05$ is removed from the research model. Because sig value is less than or equal to 0.05 , the independent variable is statistically significant. Sig values of variables PRA and TR, are 0.966 and 0.563 respectively (greater than 0.05 ), so the hypothesis 2 and 6 are not supported. The remaining independent variables satisfy the condition indicating that the variables are statistically significant. Three variables consist of BC, SP, and $\mathrm{EE}$, which have positive relationships with RAM. Three variables including OCMC, CE, and IS negatively affect to RAM. In which, IS and CE have strongest impact on RAM.

In Table 7, VIF value is used to check for multiple collinearities. In a research model with Likert scale, there have not multiple collinearities when VIF value is less than 2. As a result of the regression, all independent variables have VIF values less than 2, so no multi-collinear phenomenon occurs.

Table 7: Coefficients

\begin{tabular}{|c|c|c|c|c|c|c|c|}
\hline \multirow{2}{*}{ Model } & $\begin{array}{c}\text { Unstandardized } \\
\text { Coefficients }\end{array}$ & SC & \multirow{2}{*}{ T } & \multirow{2}{*}{ Sig. } & \multicolumn{2}{|c|}{$\begin{array}{c}\text { Collinearity } \\
\text { Statistics }\end{array}$} \\
\cline { 2 - 4 } & B & $\begin{array}{c}\text { Std. } \\
\text { Error }\end{array}$ & Beta & & & Tolerance & VIF \\
\hline (Constant) & 2.855 & .416 & & 6.863 & .000 & & \\
\hline OCMC & -.094 & .038 & -.094 & -2.494 & .013 & .789 & 1.268 \\
\hline CE & -.101 & .030 & -.129 & -3.324 & .001 & .744 & 1.343 \\
\hline PRA & -.001 & .035 & -.002 & .042 & .966 & .785 & 1.275 \\
\hline BC & .149 & .032 & .166 & 4.625 & .000 & .868 & 1.152 \\
\hline SP & .125 & .037 & .142 & 3.340 & .001 & .613 & 1.631 \\
\hline IS & -.350 & .040 & -.362 & -8.726 & .000 & .647 & 1.546 \\
\hline TR & -.025 & .043 & -.020 & -.579 & .563 & .932 & 1.073 \\
\hline EE & .095 & .031 & .128 & 3.056 & .002 & .630 & 1.586 \\
\hline & \multicolumn{7}{|c|}{ SC: Standardized Coefficients } \\
\hline
\end{tabular}

The residual test helps the study consider the validity and reliability of the model. Figure 2 shows that mean value is close to 0 , the standard deviation is 0.978 , indicating normal distribution. Therefore, it is concluded that the regression model is completely reliable to examine the impact of factors on risk assessment of material misstatement.

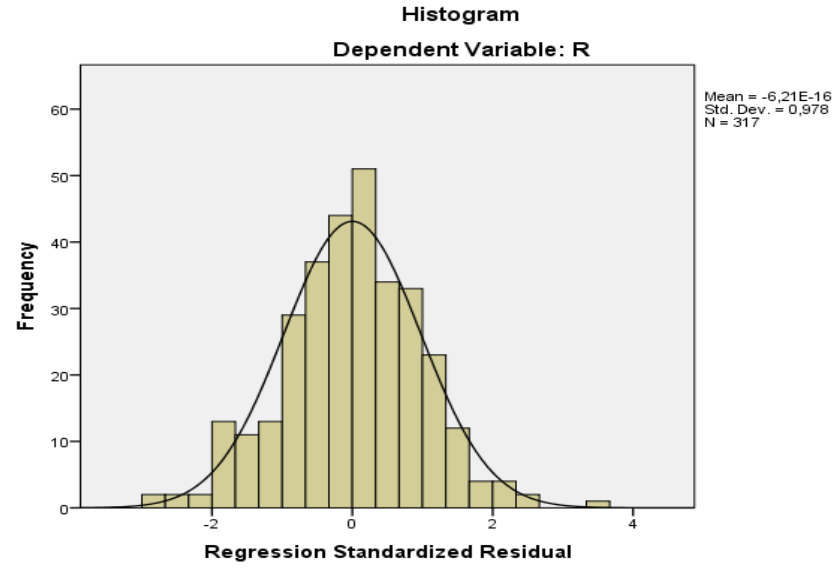

Figure 2: Histogram normalized residual frequency chart

\section{Conclusions}

Business characteristic has a negative relationship with risk assessment of material misstatement in auditing financial statements. Therefore, when assessing risks, auditors should be paid attention to the business characteristics and business risks of the listed companies. Business risks are very diverse and complex because it is affected by many factors such as political institutions, and business environment. The causes of business risks may come from the complex of political environment, economic crisis, unstable legal environment, the mistake of company leadership on business strategy, the lack of business information, the weakness in the competitiveness and management skills. Finding out the causes of business risks help auditors determine risk capability of material misstatements. In order to conduct risk assessment process, auditors can apply PEST model, 5F model, or risk-based audit approach.

Auditors evaluate risk of significant errors according to the following procedure (see Figure 3):

The research findings indicated that the factors of internal control include information systems, control environment, and monitoring controls significantly influence on the risk assessment of material misstatement. Assessment of internal control is to determine the risks that may occur in each stage. Preventive measures found are to implement effectively the goals of enterprises. Moreover, assessment of internal control plays an important role not only in the audit planning stage but also throughout the stage of the audit implementation and end. Therefore, 
appropriate solutions proposed help auditors to carry out all audit stages.

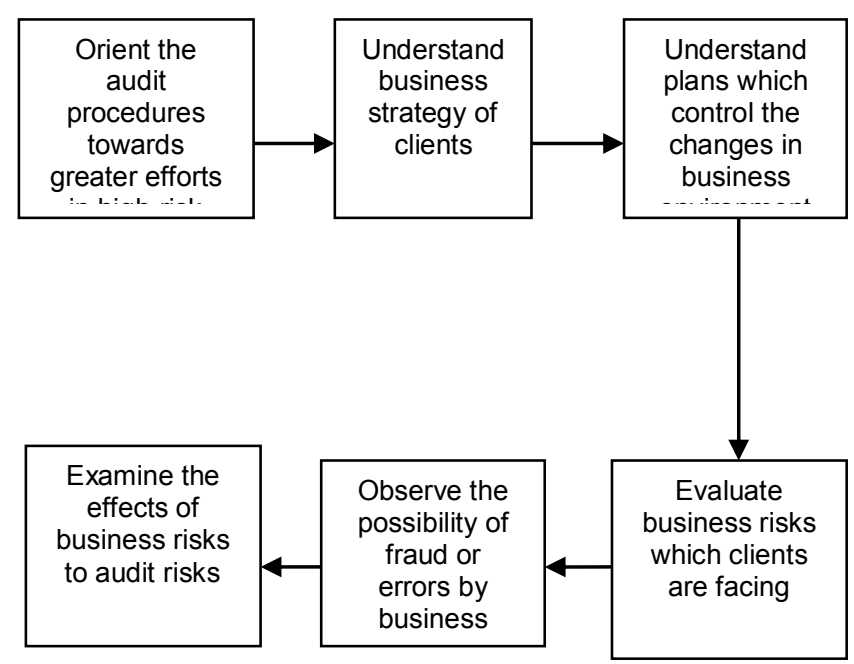

Figure 3: The process in risk assessement of material misstatement

Control Environment: The control environment includes the responsibilities of the company's staff, organizational structure, information and opinion, and the control responsibilities of the management board. These factors affect the risk of material misstatement in the process of assessing control risks. In order to evaluate risk of material misstatement through control environment, auditors should build an approach to learn about the responsibilities of the departments, employees and the managerial perspectives.

When assessing control environment, auditors can conduct interviews with employees of clients on matters such as: Are employees provided with clear orders of responsibility and duty by managers? Do employees understand their responsibility and right in their company? Do employees understand the responsibilities of the Board of Directors?. On the other hand, to evaluate the operating method of clients, auditors clearance the evaluation of the client's plan system consisting of production and business plan; consumption plan; material supply plan; investment plan; financial planning; price plan. Auditors can base on the plan system to evaluate control environment because the plan is the goal set out, the basis for making management decisions, and to assess the results. Therefore, if a plan system is good, it demonstrates the scientific management method of managers and is bases for a good assessment of control environment. Conversely, if a plan system is not good, it proves that the effectiveness of internal control in enterprises is not high and can make more risks of material misstatement.

Information System: Nowadays, when the more science and technology develop, the higher the ability to hide errors is, and the more difficult the ability to detect errors is. As a result, auditors need to equip the techniques and processes to learn internal control system, which is enable to assess enterprise's information system correctly. Auditors may use the software of professional audit documentation that can incorporate audit procedures performed and built in accordance with the different professional sectors.

In order to evaluate the enterprise information system, auditors apply an audit technique of test data. It means that auditors enter a sample of test data into the information system of clients aimed at checking whether automatic control activities correctly handle data, and produce the intended results. On the other hand, when using test data, auditors consider selecting data that covers the examined contents. Data testing is designed to ensure that software control all activities including both valid and invalid data.

\section{References}

Albrecht, W. S., Albrecht, C. O., Albrecht, C. C., \& Zimbelman, M. F. (2011). Fraud examination (6th ed.). Boston, MA: Cengage Learning.

Anderson, K. L., \& Yohn, T. L. (2002). The Effect of $10 \mathrm{k}$ restatements on firm value, information asymmetries, and investors' reliance on earnings. Retrieved from: https://ssrn.com/abstract=332380 or http://dx.doi.org/10. 2139/ssrn.332380

Arens, A. A., Elder, R. J., \& Beasley, M. S (2008). Auditing and Assurance Services - An integrated Approach $\left(12^{\text {th }}\right.$ ed.). Upper Saddle River, NJ: Prentice-Hall International.

Bell, T. B., \& Carcello, J. V. (2000). A Decision aid for assessing the likelihood of fraudulent financial reporting. Auditing: A Journal of Practice \& Theory, 19(1), 169-184. DOI: 10.2308/aud.2000.19.1.169

Beneish, M. D. (1999). The detection of earnings manipulation. Financial Analysts Journal, 55(5), 24-36. DOI: 10.2469/faj.v55.n5.2296

Bonner, S. E., Palmrose, Z. V., \& Young, S. M. (1998). Fraud type and auditor litigation: An analysis of SEC accounting and auditing enforcement releases. The Accounting Review, 73(4), 503-32.

Brazel, J., Jones, K., \& Zimbelman, M. F. (2009). Using nonfinancial measures to assess fraud risk. Journal of Accounting Research, 47(5), 1135-1166. DOI: 10.1111/j.1475679X.2009.00349.x

Chae, S. J., Nakano, M., \& Fujitani, R. (2020). Financial reporting opacity, audit quality and crash risk: Evidence from Japan. Journal of Asian Finance, Economics and Business, 7(1), 917. https://doi.org/10.13106/jafeb.2020.vol7.no1.9

Coderre, G. D. (1999). Fraud detection. Using data analysis techniques to detect fraud. Vancouver, Canada: Global Audit Publications.

Curtis, A. B., Lundholm, R. J., \& Mcvay, S. E. (2013). Forecasting 
Sales: A model and some evidence from the retail industry. Contemporary Accounting Research, 31(2), 581-608. https://doi.org/10.1111/1911-3846.12040

DeAngelo, H., DeAngelo, L., \& Skinner, D. J. (1994). Accounting choice in troubled companies. Journal of Accounting \& Economics, 17, 113-143. DOI: 10.1016/0165-4101(94)900078.

Dechow, P. M., Sloan, R. G., \& Sweeney, A. P. (1996). Causes and consequences of earnings manipulation: An analysis of firms subject to enforcement actions by the SEC. Contemporary Accounting Research, 13(1), 1-36. DOI: 10.1111/j.1911-3846.1996.tb00489.x

Dechow, P. M., Ge, W., Larson, C. R., \& Sloan, R. G. (2011). Predicting material accounting misstatements. Contemporary Accounting Research, 28(1), 17-82. DOI: 10.1111/j.19113846.2010.01041.x

DeFond, M. L., \& Jiambalvo, J. (1991). Incidence and circumstance of accounting errors. The Accounting Review, 66, 643-655.

Dikmen, B., \& Küçükkocaoğlu, G. (2010). The Detection of earnings manipulation: The three phase cutting plane algorithm using mathematical programming. Journal of Forecasting, 29(5), 442-466. DOI: 10.1002/for.1138

Ettridge, M., Scholz, S., Smith, K., \& Sun, L. (2010). How do restatements begin? Evidence of earnings management preceding restated financial reports. Journal of Business Finance and Accounting, 37, 332-355. DOI: 10.1111/j.14685957.2010.02199.x

Friedlan, J. M. (1994). Accounting choices of issuers of initial public offerings. Contemporary Accounting Research, 11(1), 1-31. DOI: 10.1111/j.1911-3846.1994.tb00434.x

Gujarati, D. N., \& Porter, D. C. (2008), Basic Econometrics (5th ed.). New York, NY: McGraw Hill.

Hair, J. F., Black, W. C., Babin, B. J., Anderson, R. E., \& Tatham, R. L. (2006). Multivariate Data Analysis (6th ed.). Upper Saddle River, NJ: Prentice-Hall International.

Healy, P. M. (1985). The effect of bonus schemes on accounting decisions. Journal of Accounting and Economics, 7(1-3), 85107.

Houston, R. W., Peters, M. F., \& JaPratt, J. H. (1999). The audit risk model, business risk and audit-planning decisions. The Accounting Review, 74(3), 281-298. DOI: 10.2308/accr.1999.74.3.281

Jensen, M. C., \& Meckling, W. H. (1976). Theory of the firm: Managerial behavior, agency costs and ownership structure. Journal of Financial Economics, 3(4), 305-360. DOI: 10.1016/0304-405X(76)90026-X

Johnstone, K., Li, C., \& Rupley, K. H. (2011). Changes in corporate governance associated with the revelation of internal control material weaknesses and their subsequent remediation. Contemporary Accounting Research, 28(1), 331-383. DOI: 10.1111/j.1911-3846.2010.01037.x

Jokipii, A. (2010). Determinants and consequences of internal control in firms: a contingency theory based analysis. Journal of Management \& Governance, 14(2), 115-144. DOI: 10.1007/s10997-009-9085-x

Jones, J. J. (1991). Earnings management during import relief investigations. Journal of Accounting Research, 29(2), 193228.
Karagiorgos, T., Drogalas, G., \& Giovanis, N. (2011). Evaluation of the effectiveness of internal audit in Greek hotel business. International Journal of Economic Sciences and Applied Research, 4(1), 19-34.

Keune, M. B. K. (2010). Auditor's misstatement materiality judgements and decisions in the post-Sarbanes-Oxley Act environment (Doctoral dissertation). Madison, WI: University of Wisconsin-Madison.

Kothari, S. P., Shu, S., \& Wysocki, P. D. (2009). Do managers withhold bad news? Journal of Accounting Research, 47(1), 241-276. DOI: 10.1111/j.1475-679X.2008.00318.x

Kreutzfeldt, R. W., \& Wallace, W. A. (1986). Error characteristics in audit populations: Their profile and relationship to environmental factors. Auditing: A Journal of Practice \& Theory, 6(1), 20-43.

Loebbecke, J. K., Eining, M. M., \& Willingham, J. J. (1989). Auditors' experience with material irregularities: Frequency, nature. Auditing: A Journal of Practice \& Theory, 9(1), 1-28.

Marinakis, P. (2011). An investigation of earnings management and earnings manipulation in the UK (Doctoral dissertation). Nottinghan, UK: University of Nottingham.

Messier, W., Glover, S., \& Prawitt, D. (2006). Auditing and assurance services: A systematic approach (5th ed.). New York, NY: McGraw Hill

Nieschwietz, R., Schultz, J., \& Zimbelman, M. (2000). Empirical research on external auditors' detection of financial statement fraud. Journal of Accounting Literature, 19, 190-246.

Norman, H. D., Lombard, J. E., Wright, J. R., Kopral. C. A., Rodriguez, J. M., \& Miller. R. H. (2011). Consequence of alternative standards for bulk tank somatic cell count of dairy herds in the United States. Journal of Dairy Science, 94(12), 6243-6256. DOI: 10.3168/jds.2011-4645

Palmrose, Z. V., Richardson, V. J., \& Scholz, S. (2004). Determinants of market reactions to restatement announcements. Journal of Accounting and Economics, 37, 59-89. DOI: 10.1016/j.jacceco.2003.06.003

Rahman, M. M., Meah, M. R., \& Chaudhory, N. U. (2018). The impact of audit characteristics on firm performance: An empirical study from an emerging economy. Journal of Asian Finance, Economics and Business, 6(1), 59-69. http://doi.org/10.13106/jafeb.2019.vol6.no1.59

Riley, R. A., Pearson, T., \& Trompeter, L. (2003). The value relevance of non-financial performance variables and accounting information: The case of the airline industry. Journal of Accounting and Public Policy, 22(3), 231-254. DOI: 10.1016/S0278-4254(03)00021-8

Romney, M. B., Albrecht, W. S., \& Cherrington, D. J. (1980). Auditors and the detection of fraud. Journal of Accountancy, 149(5), 63-69.

Sawalqa, F. A., \& Qtish, A. (2012). Internal Control and Audit Program Effectiveness: Empirical Evidence from Jordan. International Business Research, 5(9), 128-137. DOI:10.5539/ibr.v5n9p128

Schultz, J. J., Bierstaker, J. L., \& O’Donnell, E. (2010). Integrating business risk into auditor judgment about the risk of material misstatement: The influence of a strategic-systemsaudit approach. Accounting Organizations and Society, 35(2), 238-251. DOI: 10.1016/j.aos.2009.07.006

Skousen, C. J., Smith, K. R., \& Wright, K. R. (2009). Detecting 
and predicting financial statement fraud: The effectiveness of the fraud triangle and SAS No. 99. Corporate Governance and Firm Performance (Advances in Financial Economics), 13, 53-81. DOI: 10.1108/S1569-3732(2009)0000013005.

Srinivasan, S. (2005). Consequences of financial reporting failure for outside Directors: Evidence from accounting restatements and audit committee members. Journal of Accounting Research, 43(2), 291-334, DOI: $\quad 10.1111 / \mathrm{j} .1475-$ 679x.2005.00172.x
Summers, S. L., \& Sweeney, J. T. (1998). Fraudulent misstated financial statements and insider trading: An empirical analysis. The Accounting Review, 73(1), 131-146

Wilks, T. J., \& Zimbelman, M. F. (2004). Using game theory and strategic reasoning concepts to prevent and detect fraud. Accounting Horizons, 18(3), 173-184.

Zheltoukhova, K., \& Suckley, L. (2014). Hands-on or hands-off: Effective leadership and management in SMEs. Sheffield, UK: Sheffield Hallam University. 


\section{Appendix}

Appendix 1. Scale of audit planning phase

\begin{tabular}{|c|c|c|}
\hline Code & Content & Soures \\
\hline \multicolumn{3}{|c|}{ Control Environment (CE) } \\
\hline CE1 & $\begin{array}{c}\text { Responsibilities of } \\
\text { divisions/ employees in } \\
\text { enterprises are clearly } \\
\text { defined }\end{array}$ & $\begin{array}{c}\text { Sawalqa and Qtish (2012); } \\
\text { Johnstone, Li, and Rupley } \\
\text { (2011); Karagiorgos, } \\
\text { Drogalas, and Giovanis } \\
\text { (2011) }\end{array}$ \\
\hline CE2 & $\begin{array}{l}\text { A clear organizational } \\
\text { structure serves as a basis } \\
\text { for determining the } \\
\text { obligations of departments / } \\
\text { employees in enterprises }\end{array}$ & $\begin{array}{c}\text { Sawalqa and Qtish (2012); } \\
\text { Johnstone, Li, and Rupley } \\
\text { (2011); Karagiorgos, } \\
\text { Drogalas, and Giovanis } \\
\text { (2011) }\end{array}$ \\
\hline CE4 & $\begin{array}{l}\text { Separation between control } \\
\text { and management within } \\
\text { enterprises }\end{array}$ & $\begin{array}{c}\text { Sawalqa and Qtish (2012); } \\
\text { Johnstone, Li, and Rupley } \\
\text { (2011); Karagiorgos, } \\
\text { Drogalas, and Giovanis } \\
\text { (2011) }\end{array}$ \\
\hline \multicolumn{3}{|c|}{ Process of Risk Assessment (PRA) } \\
\hline PRA1 & $\begin{array}{l}\text { Enterprises have assessed } \\
\text { the obstacles that can hinder } \\
\text { the achievement of the set } \\
\text { goals }\end{array}$ & $\begin{array}{c}\text { Sawalqa and Qtish (2012); } \\
\text { Johnstone, Li, and Rupley } \\
\text { (2011); Karagiorgos, } \\
\text { Drogalas, and Giovanis } \\
\text { (2011) }\end{array}$ \\
\hline PRA2 & $\begin{array}{l}\text { Enterprises set low-risk } \\
\text { goals }\end{array}$ & $\begin{array}{l}\text { Sawalqa and Qtish (2012); } \\
\text { Johnstone, Li, and Rupley } \\
\text { (2011); Karagiorgos, } \\
\text { Drogalas, and Giovanis } \\
\text { (2011) }\end{array}$ \\
\hline PRA3 & $\begin{array}{c}\text { Enterprises have established } \\
\text { an appropriate internal audit } \\
\text { department/staff. }\end{array}$ & $\begin{array}{l}\text { Sawalqa and Qtish (2012); } \\
\text { Johnstone, Li, and Rupley } \\
\text { (2011); Karagiorgos, } \\
\text { Drogalas, and Giovanis } \\
\text { (2011) }\end{array}$ \\
\hline PRA4 & $\begin{array}{l}\text { Enterprises assess and focus } \\
\text { on specific risks associated } \\
\text { with the preparation and } \\
\text { presentation of the financial } \\
\text { statements. }\end{array}$ & Jokipii (2010) \\
\hline \multicolumn{3}{|c|}{ Operation Control (OC) } \\
\hline $\mathrm{OC} 1$ & $\begin{array}{l}\text { Events/errors which occur } \\
\text { are handled timely and } \\
\text { reasonably. }\end{array}$ & $\begin{array}{c}\text { Sawalqa and Qtish (2012); } \\
\text { Johnstone, Li, and Rupley } \\
\text { (2011); Karagiorgos, } \\
\text { Drogalas, and Giovanis } \\
(2011)\end{array}$ \\
\hline $\mathrm{OC} 2$ & $\begin{array}{l}\text { Review and evaluate the } \\
\text { effectiveness of internal } \\
\text { control based on the } \\
\text { previous internal results }\end{array}$ & $\begin{array}{c}\text { Sawalqa and Qtish (2012); } \\
\text { Johnstone, Li, and Rupley } \\
\text { (2011); Karagiorgos, } \\
\text { Drogalas, and Giovanis } \\
(2011)\end{array}$ \\
\hline
\end{tabular}

\begin{tabular}{|c|c|c|}
\hline Code & Content & Soures \\
\hline OC3 & $\begin{array}{l}\text { Internal control is } \\
\text { integrated with the full } \\
\text { accounting and finance } \\
\text { system. }\end{array}$ & $\begin{array}{c}\text { Sawalqa and Qtish (2012); } \\
\text { Johnstone, Li, and Rupley } \\
\text { (2011); Karagiorgos, } \\
\text { Drogalas, and Giovanis } \\
\text { (2011) }\end{array}$ \\
\hline OC4 & $\begin{array}{l}\text { The scope of } \\
\text { responsibilities and jobs of } \\
\text { the divisions/ employees is } \\
\text { described and updated } \\
\text { regularly and fully. }\end{array}$ & Jokipii (2010) \\
\hline \multicolumn{3}{|c|}{ Monitor the controls (MC) } \\
\hline $\mathrm{MC1}$ & $\begin{array}{l}\text { Activity information used } \\
\text { in management is recorded } \\
\text { in the system. }\end{array}$ & Jokipii (2010) \\
\hline $\mathrm{MC} 2$ & $\begin{array}{l}\text { Board of directors is } \\
\text { specially interested in daily } \\
\text { control activities. }\end{array}$ & Jokipii (2010) \\
\hline $\mathrm{MC} 3$ & $\begin{array}{l}\text { There are activities to } \\
\text { control employees }\end{array}$ & Jokipii (2010) \\
\hline $\mathrm{MC} 4$ & $\begin{array}{l}\text { Internal audit department } \\
\text { helps effectively the Board } \\
\text { of Directors to supervise } \\
\text { activities. }\end{array}$ & $\begin{array}{l}\text { Norman, Lombard, Wright, } \\
\text { Kopral, Rodriguez, and } \\
\text { Miller (2011) }\end{array}$ \\
\hline \multicolumn{3}{|c|}{ Information System (IS) } \\
\hline IS1 & $\begin{array}{l}\text { The modern equipment is } \\
\text { used. }\end{array}$ & Interview experts \\
\hline IS2 & Software is used reliable. & Interview experts \\
\hline IS3 & $\begin{array}{l}\text { The information system is } \\
\text { regularly updated, and } \\
\text { adjusted to suit the business } \\
\text { operations. }\end{array}$ & Interview experts \\
\hline \multicolumn{3}{|c|}{ Trademark (TR) } \\
\hline TR1 & $\begin{array}{c}\text { You already know } \\
\text { trademark of enterprises } \\
\text { before performing an audit. }\end{array}$ & Interview experts \\
\hline TR2 & $\begin{array}{l}\text { Your audit firms have a } \\
\text { position in the professional } \\
\text { association. }\end{array}$ & Interview experts \\
\hline TR3 & $\begin{array}{l}\text { Clients have financial } \\
\text { reputation. }\end{array}$ & Interview experts \\
\hline TR4 & $\begin{array}{l}\text { Referring to the main area } \\
\text { of the clients, you can } \\
\text { immediately think of } \\
\text { clients' name. }\end{array}$ & Interview experts \\
\hline \multicolumn{3}{|c|}{ Business characteristics (BC) } \\
\hline
\end{tabular}




\begin{tabular}{|c|c|c|}
\hline Code & Content & Soures \\
\hline $\mathrm{BC} 1$ & $\begin{array}{l}\text { Enterprises operate in } \\
\text { sensitive industry. }\end{array}$ & $\begin{array}{c}\text { Summers and Sweeney } \\
\text { (1998); } \\
\text { Loebbecke, Eining, and } \\
\text { Willingham (1989); Skousen, } \\
\text { Smith, and Wright (2009) }\end{array}$ \\
\hline $\mathrm{BC} 2$ & $\begin{array}{c}\text { Enterprises operate in } \\
\text { highly competitive field. }\end{array}$ & $\begin{array}{c}\text { Summers and Sweeney } \\
\text { (1998); } \\
\text { Loebbecke, Eining, and } \\
\text { Willingham (1989); Skousen, } \\
\text { Smith, and Wright (2009) }\end{array}$ \\
\hline $\mathrm{BC} 3$ & $\begin{array}{l}\text { Business activities are often } \\
\text { interested in the } \\
\text { community. }\end{array}$ & $\begin{array}{c}\text { Summers and Sweeney } \\
\text { (1998); } \\
\text { Loebbecke, Eining, and } \\
\text { Willingham (1989); Skousen, } \\
\text { Smith, and Wright (2009) }\end{array}$ \\
\hline \multicolumn{3}{|c|}{ Economic Environment (EE) } \\
\hline EE1 & $\begin{array}{l}\text { The system of state } \\
\text { management policies has } \\
\text { not changed during the } \\
\text { audit period. }\end{array}$ & $\begin{array}{l}\text { Zheltoukhova and Suckley } \\
\qquad(2014)\end{array}$ \\
\hline EE2 & $\begin{array}{l}\text { The system of association } \\
\text { policies is stable. }\end{array}$ & $\begin{array}{l}\text { Zheltoukhova and Suckley } \\
\text { (2014) }\end{array}$ \\
\hline EE3 & $\begin{array}{l}\text { Favorable economic } \\
\text { conditions }\end{array}$ & $\begin{array}{l}\text { Zheltoukhova and Suckley } \\
\text { (2014) }\end{array}$ \\
\hline \multicolumn{3}{|c|}{ Stakeholder pressure (SP) } \\
\hline
\end{tabular}

\begin{tabular}{|c|c|c|}
\hline Code & Content & Soures \\
\hline SP1 & $\begin{array}{l}\text { Enterprises often face } \\
\text { pressures to pay short-term } \\
\text { debts. }\end{array}$ & $\begin{array}{l}\text { DeAngelo, DeAngelo, and } \\
\text { Skinner (1994); DeFond and } \\
\text { Jiambalvo (1991); } \\
\text { Beneish (1999); Lou and } \\
\text { Wang (2011); Skousen, Smith } \\
\text { and Wright (2009) }\end{array}$ \\
\hline SP2 & $\begin{array}{l}\text { Enterprises often lack } \\
\text { capital. }\end{array}$ & $\begin{array}{l}\text { DeAngelo, DeAngelo, and } \\
\text { Skinner (1994); DeFond and } \\
\text { Jiambalvo (1991); } \\
\text { Beneish (1999); Lou and } \\
\text { Wang (2011); Skousen, } \\
\text { Smith, and Wright (2009) }\end{array}$ \\
\hline SP3 & $\begin{array}{l}\text { Enterprises are under } \\
\text { pressure from partners }\end{array}$ & $\begin{array}{c}\text { DeAngelo, DeAngelo, and } \\
\text { Skinner (1994); DeFond and } \\
\text { Jiambalvo (1991); } \\
\text { Beneish (1999); Lou and } \\
\text { Wang (2011); Skousen, } \\
\text { Smith, and Wright (2009) }\end{array}$ \\
\hline \multicolumn{3}{|c|}{ Risk Assessment of Material Misstatement (RAM) } \\
\hline RAM1 & The size of audit firms & $\begin{array}{c}\text { Bonner, Palmrose and Young } \\
\text { (1998) }\end{array}$ \\
\hline RAM2 & $\begin{array}{l}\text { Internal control in audit } \\
\text { firm }\end{array}$ & Interview experts \\
\hline RAM3 & Experience of the audit team & Interview experts \\
\hline RAM4 & Results of previous audits & Interview experts \\
\hline
\end{tabular}

